\title{
SIGNIFICANCE OF BIOPSY RESEARCH IN CRYPTORCHISM IN CHILDREN*
}

\author{
BY \\ MACIEJEWSKI ALOJZY \\ From the Department of Paediatric Surgery, Medical Academy, Lodz, Poland
}

There is a relative shortage of published papers on both the experimental and clinical problems of cryptorchism.

In addition, different and often very contradictory experimental results do not help to form a clear view of this complicated problem which has been tackled by so many authors (Bishop, 1945; Campbell, 1951; Hand, 1955; Gross and Jewett, 1956; Nelson, 1951; Robinson and Engle, 1954; Záhoř and Raboch, 1956).

It is possible, however, to assume that the essential aid to diagnosis in the case of cryptorchism is biopsy examination of undescended or cryptorchid testis. Biopsy allows us to form a histological picture of the testis in children of different ages, which may help us to decide which is the best possible moment for surgical intervention and whether the problem can be solved only by operation.

For the purposes of this report, I intend to concentrate only on the results of experiments in our Departments of Paediatric Surgery and Endocrinology and to draw conclusions from both the surgical and the histological point of view.

Our data are based on several years' work with children with cryptorchid testes between the ages of 5 and 16 years. These children numbering 70 in all underwent operation in our clinic and at the same time the testes of 36 children of this group were examined histologically after biopsy. In the period of one to three years after operation the results were checked clinically.

The 36 biopsy examinations referred to the following age-groups: 10 children from 5 to 9 years old; 14 children from 10 to 12 years; nine children from 12 to 14 years, and three children from 14 to 16 years (Table).

The histological results of the 36 cases have been classified into three development stages: static, growing and pubertal, according to proposals made by Charny and Wolgin (1957) and supplemented by Pawlikowski (1960).

* A paper read at a meeting of the British Association of Paediatric Surgeons in London, September 1962.
From these results the following conclusions have been reached.

In the boys between 5 and 9 years, when approaching 9 years of age, the operated testes were in a 'static phase'-resembling those of the normal 4-year-old children (Fig. 1). In the ages between 10 and 12 and 12 and 14 the operated testes were in the 'growing phase' and similar to those of the normal 5- to 9-year-old children (Fig. 2). In the group between 14 and 16 years the operated testes were in the 'pubertal' phase and resembled the normal ones in a child of 10 years.

From the above data we can conclude that the retardation in the development phase of a child undergoing the operation because of cryptorchism becomes more marked with the advance in the child's age. At the same time the spermatogenic function of the cryptorchid testis is declining.

During the operations, measurements of the testes were made, and it was found that the average size was approximately $2 \mathrm{~cm}$. by $1 \mathrm{~cm}$. by $0.5 \mathrm{~cm}$. in the boys of 10 to 12 years.

The consistency of the testes was rarely similar to the normal one. They were usually softer, and in the cases who had been treated hormonally for some time and in those with testes situated intraabdominally they appeared jelly-like. The testes situated intra-abdominally showed a considerable tendency to grow, and in some cases attained the size of a plum. They were very soft and it was very difficult to take them out of the internal orifice of the inguinal canal. The spontaneous

TABLE

RESULT OF BIOPSY AND OPERATION

\begin{tabular}{c|c|c}
\hline $\begin{array}{c}\text { Age of Boys } \\
\text { at Operation } \\
\text { (years) }\end{array}$ & $\begin{array}{c}\text { No. } \\
\text { of } \\
\text { Boys }\end{array}$ & Histology \\
\hline $5-9$ & 10 & Static phase; resembles 4-year-old child \\
$10-12$ & 14 \\
$12-13$ & $9\}$ & $\begin{array}{c}\text { Growing phase; resembles 5-9-year-old } \\
\text { child } \\
\text { Pubertal phase; resembles 10-year-old } \\
\text { child }\end{array}$ \\
\hline
\end{tabular}




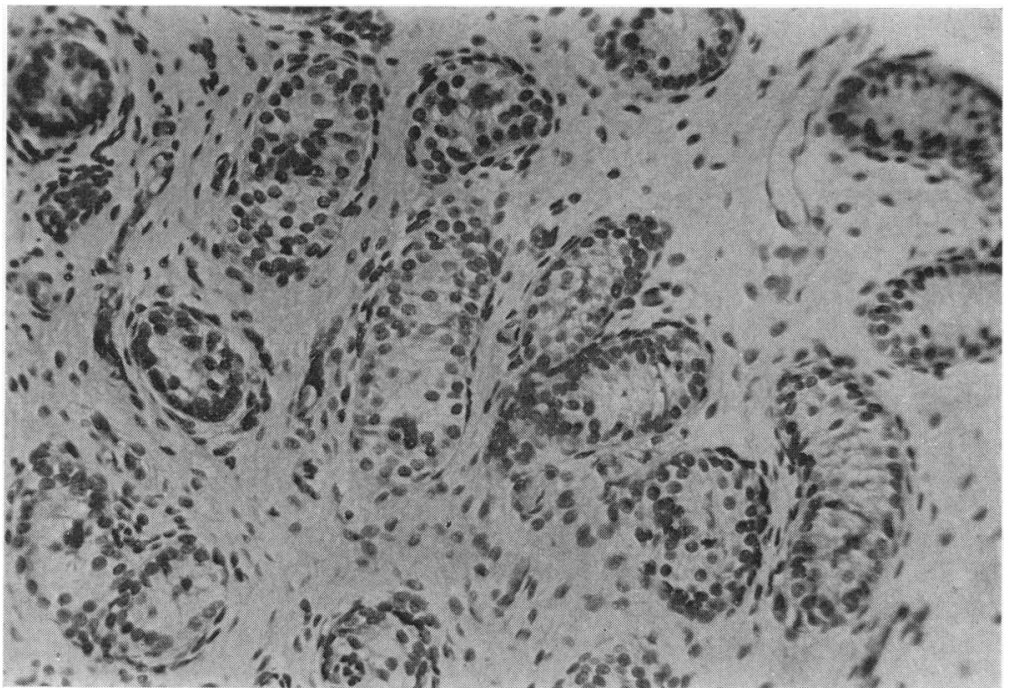

Fig. 1.-Cross-section of testis of 7-year-old boy.

Diameter of seminal tubules $50 \mu$. Sexual epithelium composed of Sertoli cells and spermatogonia. In some tubules there are exfoliative cells. The basal membrane is poorly developed. The true membrane is of normal structure. Connective tissue around seminal tubules is hyperdeveloped and shows dysgenetic characteristics. Leydig cells are absent. Structure shows a state between 'static' and 'growing' phases with some dysgenetic characteristics. The structure corresponds to the testis of a 4- to 5-year-old boy. $(\times 200$.)

descent of such a testis was not possible. Histological examinations did not reveal any greater retardation in development than in other operated testes of the same age-group.
In two cases of bilateral cryptorchism another biopsy was made within two years of the first operation. The clinical observations were as follows: An enlargement of the testis, an improve-

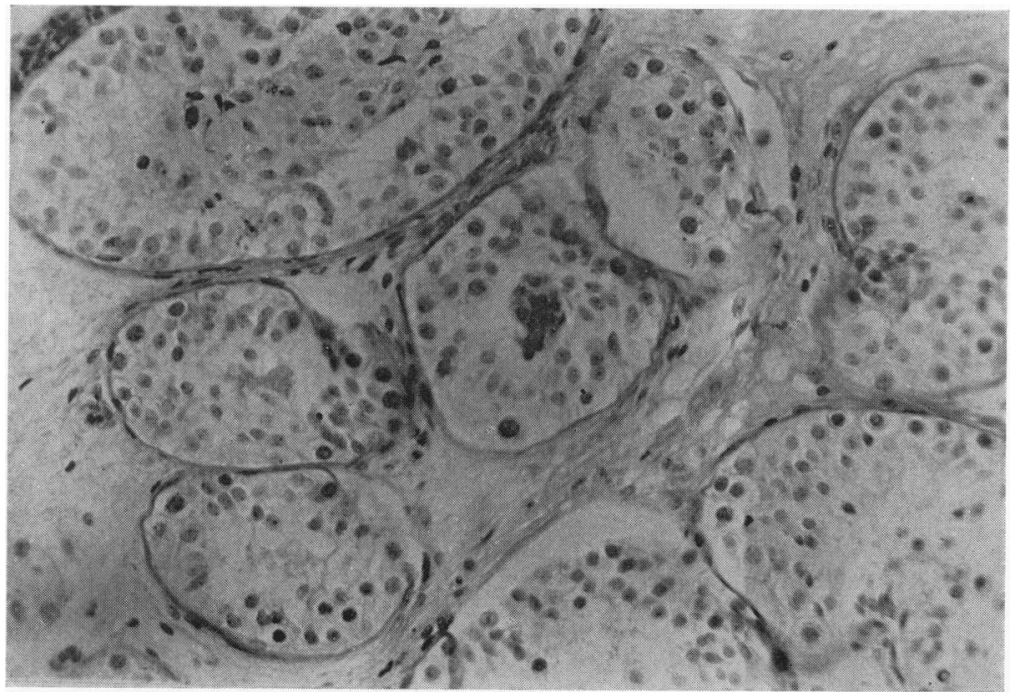

FIG. 2.-Cross-section of testis of 14-year-old boy.

Diameter of seminal tubules about $100 \mu$. Sexual epithelium in all tubules is retained. Lack of spermatogenesis and spermatogonia characteristics. In some tubules exfoliative and abortive cells can be observed. Some cells show undifferentiated character of giant cells with resistance to stain cytoplasm. Basal and true membranes are normal. Connective tissue around tubules is normal and contains abundant quantities of acidophilic serum. Leydig cells are scarce. The testis shows a structure on the boundary of the 'growing' and 'pubertal' phase, and corresponds to that of a 7- to 9-year-old boy. ( $(\times 200$. $)$ 
ment in its consistency and signs of regeneration in its histological picture. At the time of the second inspection neither clinical nor histological changes were found which could indicate any serious damage resulting from previous biopsy operations. No conclusions were drawn, however, because of the very limited number of these cases.

Besides the fact of the testis not descending into the scrotum for endocrinological or anatomical reasons, we have to deal with the morphological lesions of the testis due both to the dislocation of the organ and to its congenital defect, which is the cryptorchism.

From this material, and without going into the well-known anatomical details or experimental contradictions (the importance of which we fully appreciate), I would like to draw certain conclusions and put forward the following proposals concerning the treatment of children suffering from cryptorchism.

Surgical treatment is essential in most types of cryptorchism. In this matter one must consider the totally negative results of the hormonal therapy applied by Moore and Tapper (1940). On the other hand Thompson and Heckel (1939) could quote only $20 \%$ of cases with positive results of the treatment.
In my opinion the operation should be performed not later than the age of 6 or 7 years.

We agree with the opinion of the authors who stress the fact that the testes that have not settled down become unable to produce sperm or are impaired in the process of spermatogenesis. This fact has also been confirmed by our experiments.

\section{REFERENCES}

Bishop, P. M. F. (1945). The management of the undescended testicle. Guy's Hosp. Rep., 94, 12.

Campbell, M. F. (1951). Clinical Pediatric Urology. Saunders, London.

Charny, C. W. and Wolgin, W. (1957). Cryptorchism. Harper, New York.

Gross, R. S. and Jewett, T. C. (1956). Surgical experiences from 1,222 operations for undescended testis. J. Amer. med. Ass. 1,222 opera

Hand, J. R. (1955). Undescended testes. Trans. Amer. Ass. gen.urin. Surg., 47, 9

urin. Surg., 47, 9.
Nelson, W. O. (1951). Mammalian spermatogenesis. Recent Progr. Hormone Res., 6, 29.

Moore, N. S. and Tapper, S. M. (1940). Cryptorchidism: a theory to explain its etiology. J. Urol. (Baltimore), 43, 204.

Pawlikowski, T. (1960). The structure of male gonad in the first ten years of life. Endokr. pol., 11, 289.

Robinson, J. N. and Engle, E. T. (1954). Some observation on the cryptorchid testis. J. Urol. (Baltimore), 71, 726 .

Thompson, W. O. and Heckel, N. J. (1939). Undescended testes: present status of glandular treatment. J. Amer. med. Ass., $112,397$.

Záhớ, Z and Raboch, J. (1956). Ein Beitrag zum Problem der Hodenbiopsie bei Kryptorchismus. Schweiz. med. Wschr., 86, 311 . 